\title{
ERDŐTERÜLETEK POLLENKAPACITÁSÁNAK MODELLEZÉSE FAÁLLOMÁNYTÍPUS ÉS POLLENNAPTÁRI ADATOK ALAPJÁN
}

\author{
Rozovits Ferenc Péter ${ }^{1}$, Magyar Zsoltt ${ }^{1}$, Kottek Péter ${ }^{1}$ és Bordács Sándor ${ }^{2}$ \\ ${ }^{1} N E ́ B I H$ El Erdőtervezési és Természetvédelmi Osztály \\ ${ }^{2}$ NÉBIH MGEI Erdészeti Szaporitóanyag Felügyeleti Osztály
}

\begin{abstract}
Kivonat
Légköri pollen mérések és faállománytípus adatok felhasználásával modelltérképeket állitottunk össze a magyarországi erdőterületek becsült pollenkibocsátásáról. A modelltérképek az Országos Erdőállomány Adattár (NÉBIH Erdészeti Igazgatóság) információira épülnek és web-felületen is elérhetők (URL 4). A térképek alapján becsülhető, hogy hazánk egy-egy tájegységében mikor, milyen fafajok virágzása várható. A virágzási adatok segíthetnek a várható termés becslésében, közvetve az erdőművelési és erdőfelújitási munkák tervezésében. A modell térképek egyúttal lehetőséget biztositanak a méhlegeltetés tudatosabb tervezésére, valamint a pollenérzékenységgel kapcsolatos közegészségügyi intézkedések elökészítésére.
\end{abstract}

Kulcsszavak: faállománytípus, országos erdőállomány adattár, pollenkoncentráció, pollennaptár, pollenérzékenység, termésbecslés, méhészet.

\section{MODELING POLLEN CAPACITY OF FOREST AREAS BASED ON TREE SPECIES AND POLLEN DATA}

\begin{abstract}
Model maps were constructed for estimating pollen capacity of Hungarian forests, based on meteorological pollen monitoring and forestry database information. Model maps are continuously updated and directly linked to the National Forest Database (NÉBIH Forestry Directorate) which are publicly available at NÉBIH website (URL 4). Based on the model maps the flowering period of tree species can be forecasted in different region of Hungary. Data and information of the model maps can be used for annual seed crop prognoses and indirectly for planning of forest regenerations and silvicultural works. Model maps also provide an opportunity for more conscious planning of bee keeping and preparation of public health measures taken for pollen sensitivity.
\end{abstract}

Keywords: stock types, national forestry database, pollen concentration, pollen data, pollen sensitivity, crop estimation, bee-keeping. 


\section{BEVEZETÉS}

A hazai erdőterületek legfontosabb adatait az Országos Erdőállomány Adattár (Nemzeti Élelmiszerlánc-biztonsági Hivatal, NÉBIH) tartja nyilván. Az adatbázisban alapvetően a szakszerü erdőgazdálkodáshoz szükséges mérés, észlelés és vizsgálat alapú tényadatok, valamint az ezekből származtatott modellek segítségével előállított adatok találhatók. Az adatsorok hagyományos, erdészeti célú felhasználási irányai ismertek, így pl. a fahasználati, erdőművelési, erdőtervezési munkák alapjait biztositják. Ezen túlmenően azonban lehetőség nyílik más szakterületi irányokban is hasznositani az adatokat.

Az egyik jellemző származtatott adat a faállománytípus. A faállománytípusról tárolt információkat felhasználva erdőrészlet szintű megbízhatósággal rendelkezésre állnak az erdőt alkotó fafajok elterjedési, ill. területborítási adatai (Bartha \& Mátyás 1995). A fafajok pollenkibocsátása, annak mértéke és intenzitása egyértelmüen összefüggésben áll azok területfoglalásával. Az elterjedési adatokat kiegészitve a fafajok virágzási jellemzőivel, valamint meteorológiai, klimatikus, ill. pollenmérési adatokkal új típusú modelltérképeket készíthetünk. A modell térképek alapján erdőterületeink pollenkibocsátása jobban érzékelhetővé tehetö.

Közvetetten a kibocsátott pollen ismerete nagyon fontos információ az erdész szakemberek számára, hiszen a virágzás mértéke alapvetően meghatározza az adott évi termés mennyiségét és minőségét. A termés 'előzetes' ismerete fontos információ az őszi maggyüjtések, valamint a természetes erdőfelújitások előkészítése, szervezése szempontjából. A virágzási, pollenkibocsátási információk hasznosak lehetnek méhészeti, közegészségügyi szempontból is. A virágzási adatok feldolgozásából is látszik, hogy mely fajok virágoznak a tél végén-tavasz elején (pl. éger, nyír stb.). Április-május hónapokban a hazánkban mindenhol nagy tömegben előforduló tölgy félék virágzása jellemző.

\section{IRODALMI ÁTTEKINTÉS}

Az erdei fafajok egyedeinek virágzóképessége évenként hasonló intenzitásúnak tekinthető. Tölgy fajokon végzett virágzásbiológiai megfigyelések kimutatták, hogy a faegyedek virágzási tulajdonságai jelentősen eltérőek, de ugyanazon egyedek esetében az egyes évek között nincs érdemi eltérés a virágzási tényezőkben, mint pl. a termős-porzós füzérek száma, a füzéren fejlődő virágok száma (Bordács 1994, 1997). Pjatnyickij (1954) megfigyelései szerint a kocsánytalan tölgy porzós füzére átlagosan 550 ezer pollent tartalmaz, és az életképes virágpor 60-70 km távolságra, ill. 2000-3000 méter magasba is eljuthat. Egy 1986ban végzett megfigyelési sorozat kimutatta, hogy Nyugat-Európában a tavaszi időszakban regisztrált esős napok (átl. 40 nap / 3 hónap) ellenére a tölgyek virágporának koncentrációja jelentős (7\%) és folyamatosan kimutatható a méröállomásokon (Astinet 1989). A pollenkoncentráció egyik legföbb befolyásoló tényezője a szél, mely egy szegedi pollentranszportról készült tanulmányban került részletezésre (Makra et al 2004, 2011). A vizsgálat során nem 
csak a Kárpát-medencéből, de Franciaország központi és keleti, valamint Olaszország északi területeiről is detektáltak pollentranszportot. Esős napokon a nagytávolságú, valamint a középtávolságú pollentranszport azonos mértékünek mutatkozott.

A virágzás intenzitásában több napos eltérések is lehetnek a domborzati tényezőkböl (kitettség, mikro-domborzat stb.) adódóan. A fehér akác (Robinia pseudoacacia) esetében északi kitettségben 3 nappal később, ill. déli kitettségben 3 nappal korábban nyílnak a virágok. Ezt a virágzásban bekövetkezö eltérést a tengerszint feletti magasság is befolyásolja, 200 m szintkülönbség esetén a virágzások közötti eltérés 10 nap is lehet (Fritsch 2012).

Számos külföldi irodalom foglalkozik a pollenkibocsátással föleg a népegészségügyi vonatkozásai miatt. Korunk egyik nagy népbetegségének számító allergia vagy szénanátha (pollinosis) számos helyen előfordul és egyre gyakrabban vált ki az arra érzékenyeknél kellemetlen tüneteket. Hazánk erdeinek pollenkibocsátása befolyásolja, de nem áll egyenes arányban az allergén tünetek megjelenésével. Ugyanis az erdőállományok által kibocsátott pollen még nem kapcsolódott szennyező légköri anyagokkal, ezért nem okoz olyan mértékben tüneteket, mint a városokban, vagy azok közvetlen környezetében található pollen. Egy pekingi kutatás szerint (Wang et al 2017) a járóbetegek által felíratott antihisztaminok, ill. antiallergének korrelációs kapcsolatban állnak Peking város térségében történő pollenkibocsátási időszakokkal (márciustól áprilisig, augusztustól szeptemberig).

Egy másik tanulmány szerint (Lin et al 2002) az allergiás kockázatot jelentő fák szerepe jelentős. A vizsgálatokba 371 New York-i allergiás beteget vontak be, és végeztek el rajtuk keresztreakciós vizsgálatot. Az allergiás reakció mértéke szerint jelentős eltérések mutatkoztak a fafajok között. Az allergiás reakciókért a tölgy (34,3\%), nyír (32,9\%), juhar (32,8\%), bükk $(29,6 \%)$, hikoridió $(27,1 \%)$, köris $(26 \%)$, szil $(24,6 \%)$, ill. nyár $(20,6 \%)$ fajok pollenje volt felelős. Egy svédországi vizsgálat azt mutatta, hogy a hárs, szil, füz, juhar és a nyár pollen klinikailag irreleváns allergénforrások (Eriksson 1978).

Több tudományos elemzés is készült arról, milyen tényezők befolyásolják döntő többségben a virágzást és ezzel egyenes arányban a pollenkibocsátást. Egy parlagfü pollenszórására készített faktoranalizis során az alábbi paraméterek befolyásolták a pollenkibocsátást fontossági sorrendben: szélirány, harmatpont hömérséklet, középhömérséklet, maximum hőmérséklet, tényleges gőznyomás, globálsugárzás, telítettségi gőznyomás, napi hőmérsékletingás, minimum hőmérséklet, szélsebesség, potenciális párolgás, relatív nedvesség, légnyomás (Makra et al 2008, 2016).

Az Országos Közegészségügyi Intézet (OKI) Közegészségügyi Igazgatósága átlagosan kétévente készít összefoglaló pollenjelentést, mely során egy tanulmányban foglalják össze az észlelt pollenviszonyoknak megfelelően az éves pollennaptári állapotot. Hazánk hivatalosan nyilvántartott erdőrészleteinek pollen naptári modelljére ez a jelentés adta az alap ötletet.

Az Országos Meteorológiai Szolgálat 2015-évi jelentésében közölt országos havi középhőmérsékleti anomáliákat tartalmazó grafikon (1. ábra) mutatja, hogy a közel százéves átlaghoz képest igen nagy - mintegy $1,4^{\circ} \mathrm{C}$ - az eltérés. A hőmérsékleti anomáliák grafikonja 
illeszkedik a százéves hőmérsékletváltozási trendbe, amely során egyre gyakoribbak a szélsőségesen meleg évek, ami jelentős hatással van a növények fenofázisainak alakulására is. Azáltal, hogy már az év elejétöl fogva egy hömérsékleti többletet észlelünk a növények a megszokottnál jóval hamarabb virágozhatnak. A jelenség megfigyelhető az ÁNTSZ 2015évi jelentésében is, ahol a különböző fafajok-faállománytípusok virágzásának összecsúszását tapasztalhatjuk. Elmondható, hogy amennyiben az adott fafaj virágzásához igen kedvező hőmennyiség áll fenn, úgy a virágzás intenzitása is sokkal erősebb lesz.

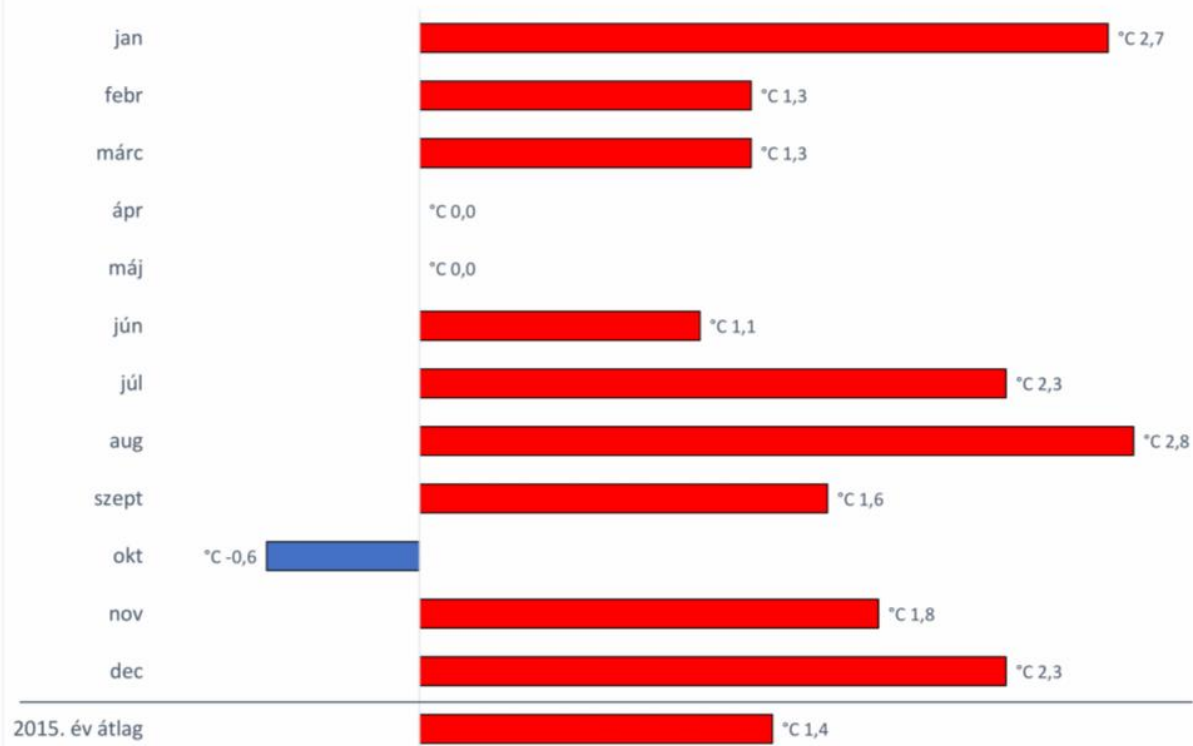

1. ábra: Az országos havi középhömérséklet eltérése a 1981-2010 közötti átlagtól 2015-ben 15 állomás homogenizált, interpolált adatai alapján (OMSZ 2016).

Figure 1: Variance of monthly mean temperature in 2015 in comparison of average of years 1981-2010, based on standardized data of 15 stations (OMSZ 2016).

A 2015-évi széljárást illetően elmondható, hogy a százéves átlagtól elmaradnak a havi szélsebességek néhány kivétellel, április szelesebb hónapnak bizonyult közel $0,2 \mathrm{~m} / \mathrm{s}$ átlagos szélsebességgel (Pestszentlőrincen mért adatsor alapján OMSZ honlapja 2016).

\section{ANYAG ÉS MÓDSZER}

A legtöbb erdőterületünk elegyes, azaz több fafaj alkotja az erdőrészleteket, mely fafajok sokszor különböző időszakban virágoznak. Mivel emiatt a fafajok alapján nem lehetett volna egyértelmüen besorolni az erdőrészleteket fenológiájuk szerint, ezért kézenfekvő volt a faállománytípus (FATI) használata. A faállománytípus egy aggregált jellemző, de az adott erdőrészletben előforduló fafajokról elegendő és összefüggéseket is tartalmazó információt 
biztosít. A faállománytípus az Országos Erdőállomány Adattárban (továbbiakban: Adattár) elsősorban fafajsor szintű adatokból, algoritmikusan, egységes elvek szerint kerül meghatározásra, és minden erdőrészletre vonatkozóan rendelkezésre áll. Jellemzően a számítás során a faállomány felső- és alsó szintű fafajsoraiból, valamint az erdősítési elöírások alapján határozzuk meg a faállomány típusát. Folyamatban lévő erdősités esetén a felújitási szint faállománytípusa érvényes, ennek hiányában (üres területeknél) az első helyen szereplő erdősítési előirás faállománytípusát használjuk.

Az Adattárban nyilvántartott faállománytípusok területének változása (az összes erdőterülethez képest) a mérlegkimutatások szerint 2012-2015 között 3,5\% volt, míg 2015-2017 között 1,6\% volt. Ez alapján kijelenthető, hogy rövidtávon a faállományadatok jelentősen nem változnak, azaz az erdőterület adatok a modellezéshez megfelelően statikusnak tekinthetők. Jelen tanulmányban a modellezéshez az Adattár 2017. július 6-án rögzített állapotadatait használtuk fel.

A faállománytípusokat feltételezett pollenkibocsátásuk alapján kategorizáltuk, amelyhez az ÁNTSZ Aerobiológiai Hálózatának 2016-ben kiadott tájékoztatójában szereplő modelltáblát használtuk fel (URL 3).

A mérési adatokból kitünik, hogy az augusztus-december közötti időszakban a fafajok pollenkibocsátása nem mérhető vagy jelentéktelen, ezért a modellezéshez csak a december-július közötti időszakot vettük figyelembe. A modelltábla négyfokozatú, színkódos bonitálási skálát alkalmaz a pollenkibocsátás mértékére. A színkódos besorolást a 1. táblázat tartalmazza.

1. táblázat: A pollenkibocsátás mértékének ÁNTSZ jelentés szerinti színkódolása (OKK-OKI honlapja 2016).

Table 1: Color coding of pollen emissions according to the ÁNTSZ report (OKK-OKI website 2016).

\begin{tabular}{|c|c|}
\hline $\begin{array}{c}\text { Kód, } \\
\text { színkód }\end{array}$ & Pollenkibocsátás mértéke \\
\hline 0 & nincs érték \\
\hline 1 & az adott héten a pollenkoncentráció csak alacsony szintet ért el \\
\hline 2 & az adott héten a pollenkoncentráció legalább egy napon elérte a közepes szintet \\
\hline 3 & az adott héten a pollenkoncentráció legalább egy napon elérte a magas szintet \\
\hline
\end{tabular}

Az Adattárban nyilvántartott 101-féle faállománytípushoz hozzárendeltük a pollenkibocsátás színkódjait, a pollenkibocsátás szempontjából fontos 8 naptári hónapos (decemberjúlius) időszakra, havonkénti bontásban. A faállománytípus és az adott hónapra eső pollenkoncentráció becsült értéke alapján kialakított besorolást a 2. táblázat tartalmazza. Azoknál a fajoknál, amelyek rovarbeporzásúak, tehát jelentős pollent nem bocsátanak ki és a méhlegeltetés szempontjából kiemelendők (pl. akác) jó alapot szolgáltatott a virágzási adatok megfigyelése, melyeket az Országos Magyar Méhészeti Egyesület honlapján lehet elérni (URL 1). 
2. táblázat: Az Adattárban nyilvántartott 101 faállománytípus havi pollenkibocsátási modellje a 2015-évi pollenkibocsátásnak megfeleltetve az ÁNTSZ Aerobiológiai Hálózatának tájékoztatója alapján

(OKK-OKI 2016).

Table 2: Month basis pollen emission model for 101 stock types registered in the Database according to the pollen emissions of 2015 based on the information provided by the Aerobiotic Network of ÁNTSZ

(OKK-OKI 2016).

\begin{tabular}{|c|c|c|c|c|c|c|c|c|c|c|}
\hline $\begin{array}{l}\text { Rövid } \\
\text { név }\end{array}$ & Faállománytípus neve & $\begin{array}{l}\text { Fafajok aránya az adott } \\
\text { FATI-n belül }\end{array}$ & Jan. & Febr. & Márc. & Ápr. & Máj. & Jún. & Júl. & Dec. \\
\hline B & Bükkös & $B>=70 \%$ & 0 & 0 & 0 & 1 & 1 & 0 & 0 & 0 \\
\hline B-KTT & $\begin{array}{l}\text { Kocsánytalan tölgyes- } \\
\text { bükkös }\end{array}$ & В $50-70 \%$; КTT 20-30\% & 0 & 0 & 0 & 1 & 1 & 0 & 0 & 0 \\
\hline $\begin{array}{l}\text { B-GY- } \\
\text { KTT }\end{array}$ & $\begin{array}{c}\text { Gyertyános-kocsánytalan } \\
\text { tölgyes-bükkös }\end{array}$ & $\begin{array}{c}\text { B 50-60\%; KTT 20-30\%; } \\
\text { GY } 10-20 \%\end{array}$ & 0 & 0 & 0 & 1 & 1 & 0 & 0 & 0 \\
\hline B-GY & Gyertyános-bükkös & B $50-70 \%$; GY $20-30 \%$ & 0 & 0 & 0 & 1 & 1 & 0 & 0 & 0 \\
\hline B-K & Körises-bükkös & В $50-70 \% ;$ K 20-30\% & 0 & 0 & 0 & 1 & 1 & 0 & 0 & 0 \\
\hline$B-E L$ & Egyéb lomb elegyes-bükkös & $\begin{array}{c}\text { B } 50-70 \% \\
\text { EL } 20-30 \% \text { (pl. EH) } \\
\end{array}$ & 0 & 0 & 0 & 1 & 1 & 0 & 0 & 0 \\
\hline$B-F$ & Fenyő elegyes-bükkös & В $50-70 \%$; F 20-30\% & 0 & 0 & 0 & 1 & 1 & 0 & 0 & 0 \\
\hline GY-KTT & $\begin{array}{c}\text { Gyertyános-kocsánytalan } \\
\text { tölgyes }\end{array}$ & KTT 50-70\%; GY 20-30\% & 0 & 0 & 0 & 2 & 2 & 0 & 0 & 0 \\
\hline $\begin{array}{c}\text { GY-KTT- } \\
\text { B }\end{array}$ & $\begin{array}{l}\text { Bükkös-gyertyános- } \\
\text { kocsánytalan tölgyes }\end{array}$ & $\begin{array}{c}\text { KTT 50-60\%; GY } 10-20 \% \\
\text { B } 20-30 \%\end{array}$ & 0 & 0 & 0 & 2 & 2 & 0 & 0 & 0 \\
\hline $\begin{array}{c}\text { GY-KTT- } \\
\text { CS }\end{array}$ & $\begin{array}{l}\text { Cseres- gyertyános- } \\
\text { kocsánytalan tölgyes }\end{array}$ & $\begin{array}{c}\text { KTT 50-60\%; GY 10-20\%; } \\
\text { CS 20-30\% }\end{array}$ & 0 & 0 & 0 & 2 & 2 & 0 & 0 & 0 \\
\hline $\begin{array}{l}\text { GY-KTT- } \\
\text { EL }\end{array}$ & $\begin{array}{c}\text { Egyéb lombelegyes-gyertyá- } \\
\text { nos-kocsánytalan tölgyes }\end{array}$ & $\begin{array}{c}\text { KTT 50-60\%; GY 10-20\%; } \\
\text { EL } 20-30 \%\end{array}$ & 0 & 0 & 0 & 2 & 2 & 0 & 0 & 0 \\
\hline $\begin{array}{c}\text { GY-KTT- } \\
\text { F }\end{array}$ & $\begin{array}{c}\text { Fenyő elegyes- gyertyános- } \\
\text { kocsánytalan tölgyes }\end{array}$ & $\begin{array}{c}\text { KTT 50-60\%; GY 10-20\%; } \\
\text { F 20-30\% }\end{array}$ & 0 & 0 & 0 & 2 & 2 & 0 & 0 & 0 \\
\hline GY-KST & $\begin{array}{c}\text { Gyertyános-kocsányos } \\
\text { tölgyes }\end{array}$ & KST 50-70\%; GY 20-30\% & 0 & 0 & 0 & 2 & 2 & 0 & 0 & 0 \\
\hline $\begin{array}{l}\text { GY-KST- } \\
\text { CS }\end{array}$ & $\begin{array}{l}\text { Cseres-gyertyános- } \\
\text { kocsányos tölgyes }\end{array}$ & $\begin{array}{c}\text { KST 50-60\%; GY 10-20\%; } \\
\text { CS } 20-30 \%\end{array}$ & 0 & 0 & 0 & 2 & 2 & 0 & 0 & 0 \\
\hline $\begin{array}{c}\text { GY-KST- } \\
\text { EL }\end{array}$ & $\begin{array}{l}\text { Egyéb lomb elegyes-gyer- } \\
\text { tyános-kocsányos tölgyes }\end{array}$ & $\begin{array}{c}\text { KST 50-60\%; GY 10-20\%; } \\
\text { EL 20-30\% }\end{array}$ & 0 & 0 & 0 & 2 & 2 & 0 & 0 & 0 \\
\hline $\begin{array}{c}\text { GY-KST- } \\
\text { F }\end{array}$ & $\begin{array}{c}\text { Fenyő elegyes -gyertyános- } \\
\text { kocsányos tölgyes }\end{array}$ & $\begin{array}{c}\text { KTT 50-60\%; GY 10-20\%; } \\
\text { F 20-30\% }\end{array}$ & 0 & 0 & 0 & 2 & 2 & 0 & 0 & 0 \\
\hline KTT & Kocsánytalan tölgyes & KTT $>=70 \%$ & 0 & 0 & 0 & 3 & 2 & 1 & 0 & 0 \\
\hline KTT-CS & Cseres-kocsánytalan tölgyes & $\begin{array}{c}\text { KTT } 50-70 \% \text {; CS } 20-40 \% ; \\
\text { (MOT) }\end{array}$ & 0 & 0 & 0 & 3 & 2 & 1 & 0 & 0 \\
\hline KTT-H & Hársas-kocsánytalan tölgyes & KTT 50-70\%; H 20-30\% & 0 & 0 & 0 & 3 & 2 & 1 & 0 & 0 \\
\hline $\begin{array}{l}\text { KTT- } \\
\text { MOT }\end{array}$ & $\begin{array}{c}\text { Molyhos tölgyes- } \\
\text { kocsánytalan tölgyes }\end{array}$ & $\begin{array}{c}\text { KTT 40-60\%; MOT 20-30\%; } \\
\text { (CS) }\end{array}$ & 0 & 0 & 0 & 3 & 2 & 1 & 0 & 0 \\
\hline $\begin{array}{c}\text { KTT-CS- } \\
\text { EF }\end{array}$ & $\begin{array}{l}\text { Cseres-erdeifenyves- } \\
\text { kocsánytalan tölgyes }\end{array}$ & $\begin{array}{c}\text { KTT } 50-70 \% ; \text { CS 20-30\%; } \\
\text { EF } 10-30 \%\end{array}$ & 0 & 0 & 0 & 3 & 2 & 1 & 0 & 0 \\
\hline KTT-EF & $\begin{array}{c}\text { Erdeifenyves-kocsánytalan } \\
\text { tölgyes }\end{array}$ & $\begin{array}{c}\text { KTT 50-70\%; EF 20-30\%; } \\
(\mathrm{B}, \mathrm{GY})\end{array}$ & 0 & 0 & 0 & 3 & 2 & 1 & 0 & 0 \\
\hline KTT-EL & $\begin{array}{l}\text { Egyéb lomb elegyes- } \\
\text { kocsánytalan tölgyes }\end{array}$ & KTT 50-70\%; EL 20-30\% & 0 & 0 & 0 & 3 & 2 & 1 & 0 & 0 \\
\hline
\end{tabular}




\begin{tabular}{|c|c|c|c|c|c|c|c|c|c|c|}
\hline $\begin{array}{l}\text { Rövid } \\
\text { név }\end{array}$ & Faállománytípus neve & $\begin{array}{l}\text { Fafajok aránya az adott } \\
\text { FATI-n belül }\end{array}$ & Jan. & Febr. & Márc. & Ápr. & Máj. & Jún. & Júl. & Dec. \\
\hline $\begin{array}{l}\text { KTT- } \\
\text { EGYF }\end{array}$ & $\begin{array}{l}\text { Egyéb fenyő elegyes- } \\
\text { kocsánytalan tölgyes }\end{array}$ & KTT 50-70\%; EF 20-30\% & 0 & 0 & 0 & 3 & 2 & 1 & 0 & 0 \\
\hline KST & Kocsányos tölgyes & $\mathrm{KST}>=70 \%$ & 0 & 0 & 0 & 3 & 2 & 1 & 0 & 0 \\
\hline KST-CS & Cseres-kocsányos tölgyes & KST $50-70 \%$; CS $20-30 \%$ & 0 & 0 & 0 & 3 & 2 & 1 & 0 & 0 \\
\hline $\begin{array}{l}\text { KST- } \\
\text { HNY }\end{array}$ & $\begin{array}{c}\text { Hazai nyáras-kocsányos } \\
\text { tölgyes }\end{array}$ & KST 50-70\%; HNY 20-30\% & 0 & 0 & 0 & 3 & 2 & 1 & 0 & 0 \\
\hline KST-MÉ & $\begin{array}{c}\text { Mézgás égeres-kocsányos } \\
\text { tölgyes }\end{array}$ & KST 50-70\%; MÉ 20-30\% & 0 & 0 & 0 & 3 & 2 & 1 & 0 & 0 \\
\hline KST-K & Körises-kocsányos tölgyes & KST $50-70 \%$; K 20-30\% & 0 & 0 & 0 & 3 & 2 & 1 & 0 & 0 \\
\hline KST-EL & $\begin{array}{l}\text { Egyéb lomb elegyes- } \\
\text { kocsányos tölgyes }\end{array}$ & KST 50-70\%; EL 20-30\% & 0 & 0 & 0 & 3 & 2 & 1 & 0 & 0 \\
\hline KST-F & $\begin{array}{l}\text { Fenyő elegyes- } \\
\text { kocsányos tölgyes }\end{array}$ & KST 50-70\%; F 20-30\% & 0 & 0 & 0 & 3 & 2 & 1 & 0 & 0 \\
\hline CS & Cseres & $C S>=70 \%$ & 0 & 0 & 0 & 3 & 2 & 1 & 0 & 0 \\
\hline CS-KTT & Kocsánytalan tölgyes-cseres & CS 50-70\%; KTT 20-30\% & 0 & 0 & 0 & 3 & 2 & 1 & 0 & 0 \\
\hline CS-KST & Kocsányos tölgyes-cseres & CS $50-70 \%$; KST 20-30\% & 0 & 0 & 0 & 3 & 2 & 1 & 0 & 0 \\
\hline CS-MOT & Molyhos tölgyes-cseres & $\begin{array}{l}\text { CS 50-70\%; MOT 20-30\% } \\
\text { (KTT) }\end{array}$ & 0 & 0 & 0 & 3 & 2 & 1 & 0 & 0 \\
\hline CS-EL & Egyéb lomb elegyes-cseres & CS 50-70\%; EL 20-30\% & 0 & 0 & 0 & 3 & 2 & 1 & 0 & 0 \\
\hline CS-EF & Erdeifenyves-cseres & CS 50-70\%; EF 20-30\% & 0 & 0 & 0 & 3 & 2 & 1 & 0 & 0 \\
\hline CS-FF & Feketefenyves-cseres & CS 50-70\%; FF $20-30 \%$ & 0 & 0 & 0 & 3 & 2 & 1 & 0 & 0 \\
\hline $\begin{array}{l}\text { CS- } \\
\text { EGYF }\end{array}$ & Egyéb fenyő elegyes-cseres & CS 50-70\%; EGYF 20-30\% & 0 & 0 & 0 & 3 & 2 & 1 & 0 & 0 \\
\hline MOT-VK & $\begin{array}{l}\text { Virágos kőrises- } \\
\text { molyhos tölgyes }\end{array}$ & $\begin{array}{c}\text { MOT 40-60\%; VK >=30 } \\
(\mathrm{CS}, \mathrm{KTT})\end{array}$ & 0 & 0 & 0 & 3 & 2 & 1 & 0 & 0 \\
\hline $\begin{array}{l}\text { MOT- } \\
\text { KTT }\end{array}$ & $\begin{array}{c}\text { Kocsánytalan tölgyes- } \\
\text { molyhos tölgyes }\end{array}$ & $\begin{array}{c}\text { MOT 40-50\%; KTT } 20-30 \% \\
\text { (CS) }\end{array}$ & 0 & 0 & 0 & 3 & 2 & 1 & 0 & 0 \\
\hline MOT-CS & Cseres-molyhos tölgyes & $\begin{array}{c}\text { MOT 40-50\%; CS 20-30\% } \\
\text { (KTT) }\end{array}$ & 0 & 0 & 0 & 3 & 2 & 1 & 0 & 0 \\
\hline MOT-E & $\begin{array}{l}\text { Egyéb elegyes- } \\
\text { molyhos tölgyes }\end{array}$ & $\begin{array}{c}\text { MOT 40-50\%; } \\
\text { Elegyfafaj } 50-60 \% \\
\end{array}$ & 0 & 0 & 0 & 3 & 2 & 1 & 0 & 0 \\
\hline A & Akácos & $A>=70 \%$ & 0 & 0 & 0 & 0 & 2 & 2 & 0 & 0 \\
\hline A-NNY & Nemes nyáras-akácos & A $50-70 \%$; NNY $20-30 \%$ & 0 & 0 & 0 & 0 & 2 & 2 & 0 & 0 \\
\hline A-HNY & Hazai nyáras-akácos & A $50-70 \%$; HNY $20-30 \%$ & 0 & 0 & 0 & 0 & 2 & 2 & 0 & 0 \\
\hline A-EL & Egyéb lomb elegyes-akácos & A $50-70 \%$; EL 20-30\% & 0 & 0 & 0 & 0 & 2 & 2 & 0 & 0 \\
\hline$A-F$ & Fenyő elegyes-akácos & A $50-70 \%$; EGYF $20-30 \%$ & 0 & 0 & 0 & 0 & 2 & 2 & 0 & 0 \\
\hline GY & Gyertyános & GY>=70\% & 0 & 0 & 0 & 2 & 1 & 0 & 0 & 0 \\
\hline GY-E & Elegyes-gyertyános & $\begin{array}{c}\text { GY } 50-70 \% \\
\text { Elegyfafaj } 30-50 \%\end{array}$ & 0 & 0 & 0 & 2 & 1 & 0 & 0 & 0 \\
\hline $\mathrm{J}$ & Juharos & $J>=70 \%$ & 0 & 1 & 2 & 2 & 1 & 0 & 0 & 0 \\
\hline J-E & Elegyes-juharos & $\begin{array}{c}\text { J } 50-70 \% ; \\
\text { Elegyfafaj } 30-50 \%\end{array}$ & 0 & 1 & 2 & 2 & 1 & 0 & 0 & 0 \\
\hline
\end{tabular}




\begin{tabular}{|c|c|c|c|c|c|c|c|c|c|c|}
\hline $\begin{array}{l}\text { Rövid } \\
\text { név }\end{array}$ & Faállománytípus neve & $\begin{array}{l}\text { Fafajok aránya az adott } \\
\text { FATI-n belül }\end{array}$ & Jan. & Febr. & Márc. & Ápr. & Máj. & Jún. & Júl. & Dec \\
\hline K & Körises & $\mathrm{K}>=70 \%$ & 0 & 1 & 2 & 3 & 3 & 1 & 0 & 0 \\
\hline K-T & Tölgyes-kőrises & K 50-70\%; T 20-30\% & 0 & 1 & 2 & 3 & 3 & 1 & 0 & 0 \\
\hline K-E & Egyéb elegyes-kőrises & $\begin{array}{c}\text { K } 50-70 \% ; \\
\text { Elegyfafaj } 30-50 \%\end{array}$ & 0 & 1 & 2 & 3 & 3 & 1 & 0 & 0 \\
\hline VT & Vörös tölgyes & VT $>=70 \%$ & 0 & 0 & 0 & 3 & 2 & 1 & 0 & 0 \\
\hline FD & Fekete diós & $\mathrm{FD}>=70 \%$ & 0 & 0 & 0 & 2 & 1 & 0 & 0 & 0 \\
\hline EKL & Egyéb kemény lombos & $E K L>=70 \%$ & 0 & 0 & 0 & 2 & 1 & 0 & 0 & 0 \\
\hline NNY & Nemes nyáras & $N N Y>=70 \%$ & 0 & 0 & 2 & 2 & 1 & 0 & 0 & 0 \\
\hline $\begin{array}{l}\text { NNY- } \\
\text { HNY }\end{array}$ & Hazai nyáras-nemes nyáras & NNY 50-70\%; HNY 20-30\% & 0 & 0 & 2 & 2 & 1 & 0 & 0 & 0 \\
\hline NNY-A & Akácos-nemes nyáras & NNY $50-70 \%$; A $20-30 \%$ & 0 & 0 & 2 & 2 & 1 & 0 & 0 & 0 \\
\hline NNY-EL & $\begin{array}{l}\text { Egyéb lomb elegyes- } \\
\text { nemes nyáras }\end{array}$ & NNY 50-70\%; EL 20-30\% & 0 & 0 & 2 & 2 & 1 & 0 & 0 & 0 \\
\hline NNY-F & $\begin{array}{c}\text { Fenyő elegyes-nemes } \\
\text { nyáras }\end{array}$ & NNY $50-70 \% ;$ F 20-30\% & 0 & 0 & 2 & 2 & 1 & 0 & 0 & 0 \\
\hline NFÜ & Nemes füzes & NFÜ $>=70 \%$ & 0 & 0 & 2 & 2 & 1 & 0 & 0 & 0 \\
\hline NFÜ-E & Elegyes-nemes füzes & $\begin{array}{c}\text { NFÜ } 50-70 \% ; \\
\text { Elegyfafaj } 30-50 \%\end{array}$ & 0 & 0 & 2 & 2 & 1 & 0 & 0 & 0 \\
\hline HNY & Hazai nyáras & $\mathrm{HNY}>=70 \%$ & 0 & 0 & 2 & 2 & 1 & 0 & 0 & 0 \\
\hline $\begin{array}{l}\text { HNY- } \\
\text { NNY }\end{array}$ & Nemes nyáras-hazai nyáras & HNY 50-70\%; NNY 20-30\% & 0 & 0 & 2 & 2 & 1 & 0 & 0 & 0 \\
\hline HNY-A & Akácos-hazai nyáras & HNY $50-70 \%$; A $20-30 \%$ & 0 & 0 & 2 & 2 & 1 & 0 & 0 & 0 \\
\hline $\begin{array}{l}\text { HNY- } \\
\text { KST }\end{array}$ & $\begin{array}{l}\text { Kocsányos tölgyes- } \\
\text { hazai nyáras }\end{array}$ & HNY 50-70\%; KST 20-30\% & 0 & 0 & 2 & 2 & 1 & 0 & 0 & 0 \\
\hline HNY-EL & $\begin{array}{l}\text { Egyéb lomb elegyes- } \\
\text { hazai nyáras }\end{array}$ & HNY 50-70\%; EL 20-30\% & 0 & 0 & 2 & 2 & 1 & 0 & 0 & 0 \\
\hline HNY-BO & Borókás-hazai nyáras & $\begin{array}{c}\text { FRNY, SZNY 60-80\% } \\
\text { BO 10-30\% (EL) }\end{array}$ & 0 & 0 & 2 & 2 & 1 & 0 & 0 & 0 \\
\hline HNY-F & Fenyő elegyes-hazai nyáras & HNY $50-70 \% ;$ F $20-30 \%$ & 0 & 0 & 2 & 2 & 1 & 0 & 0 & 0 \\
\hline FÜ & Füzes & FÛ $>=70 \%$ & 0 & 0 & 2 & 2 & 1 & 0 & 0 & 0 \\
\hline FÜ-E & Elegyes-füzes & $\begin{array}{c}\text { FÜ } 50-70 \% ; \\
\text { Elegyfafaj } 30-50 \% \\
\end{array}$ & 0 & 0 & 2 & 2 & 1 & 0 & 0 & 0 \\
\hline MÉ & Mézgás égeres & MÉ> $=70 \%$ & 1 & 2 & 3 & 1 & 0 & 0 & 0 & 1 \\
\hline MÉ-E & Elegyes-mézgás égeres & $\begin{array}{c}\text { MÉ } 50-70 \% \\
\text { Elegyfafaj 30-50\% }\end{array}$ & 1 & 2 & 3 & 1 & 0 & 0 & 0 & 1 \\
\hline $\mathrm{H}$ & Hársas & $H>=70 \%$ & 0 & 0 & 0 & 0 & 1 & 2 & 1 & 0 \\
\hline $\mathrm{H}-\mathrm{E}$ & Elegyes-hársas & $\begin{array}{c}\text { H } 50-70 \% ; \\
\text { Elegyfafaj } 30-50 \%\end{array}$ & 0 & 0 & 0 & 0 & 1 & 2 & 1 & 0 \\
\hline NYI & Nyíres & $N Y \mid>=70 \%$ & 0 & 0 & 0 & 2 & 3 & 1 & 0 & 0 \\
\hline NYI-E & Elegyes-nyíres & $\begin{array}{c}\text { NYI 50-70\%; } \\
\text { Elegyfafaj 30-50\% }\end{array}$ & 0 & 0 & 0 & 2 & 3 & 1 & 0 & 0 \\
\hline ELL & Egyéb lágy lombos & ELL $>=70 \%$ & 0 & 0 & 0 & 2 & 2 & 1 & 0 & 0 \\
\hline
\end{tabular}




\begin{tabular}{|c|c|c|c|c|c|c|c|c|c|c|}
\hline $\begin{array}{c}\text { Rövid } \\
\text { név }\end{array}$ & Faállománytípus neve & $\begin{array}{c}\text { Fafajok aránya az adott } \\
\text { FATI-n belül }\end{array}$ & Jan. & Febr. & Márc. & Ápr. & Máj. & Jún. & Júl. & Dec. \\
\hline $\mathrm{EF}$ & Erdeifenyves & $E F>=70 \%$ & 0 & 0 & 1 & 1 & 3 & 2 & 1 & 0 \\
\hline EF-B & Bükkös-erdeifenyves & EF $50-70 \%$; B $20-30 \%$ & 0 & 0 & 1 & 1 & 3 & 2 & 1 & 0 \\
\hline $\begin{array}{c}\text { EF-GY- } \\
\text { KTT }\end{array}$ & $\begin{array}{l}\text { Gyertyános-kocsánytalan } \\
\text { tölgyes-erdeifenyves }\end{array}$ & $\begin{array}{c}\text { EF 50-60\%; KTT 20-30\%; } \\
\text { GY 10-20\% }\end{array}$ & 0 & 0 & 1 & 1 & 3 & 2 & 1 & 0 \\
\hline EF-T & Tölgyes-erdeifenyves & EF $50-70 \%$; KTT $20-30 \%$ & 0 & 0 & 1 & 1 & 3 & 2 & 1 & 0 \\
\hline EF-CS & Cseres-erdeifenyves & EF $50-70 \%$; CS $20-30 \%$ & 0 & 0 & 1 & 1 & 3 & 2 & 1 & 0 \\
\hline EF-A & Akácos-erdeifenyves & EF $50-70 \%$; A $20-30 \%$ & 0 & 0 & 1 & 1 & 3 & 2 & 1 & 0 \\
\hline EF-EL & $\begin{array}{l}\text { Egyéb lomb elegyes- } \\
\text { erdeifenyves }\end{array}$ & EF 50-70\%; EL 20-30\% & 0 & 0 & 1 & 1 & 3 & 2 & 1 & 0 \\
\hline EF-F & Fenyő elegyes-erdeifenyves & EF $50-70 \% ; F 20-30 \%$ & 0 & 0 & 1 & 1 & 3 & 2 & 1 & 0 \\
\hline $\mathrm{FF}$ & Feketefenyves & $\mathrm{FF}>=70 \%$ & 0 & 0 & 1 & 1 & 3 & 2 & 1 & 0 \\
\hline FF-CS & Cseres-feketefenyves & FF $50-70 \%$; CS $20-30 \%$ & 0 & 0 & 1 & 1 & 3 & 2 & 1 & 0 \\
\hline FF-T & Tölgyes-feketefenyves & FF 50-70\%; MOT 20-30\% & 0 & 0 & 1 & 1 & 3 & 2 & 1 & 0 \\
\hline FF-EL & $\begin{array}{c}\text { Egyéb lomb elegyes-fekete- } \\
\text { fenyves }\end{array}$ & FF 50-70\%; EL 20-30\% & 0 & 0 & 1 & 1 & 3 & 2 & 1 & 0 \\
\hline FF-F & $\begin{array}{l}\text { Fenyő elegyes- } \\
\text { feketefenyves }\end{array}$ & FF $50-70 \%$; F 20-30\% & 0 & 0 & 1 & 1 & 3 & 2 & 1 & 0 \\
\hline LF & Lucfenyves & $L F>=70 \%$ & 0 & 0 & 1 & 1 & 3 & 2 & 1 & 0 \\
\hline LF-B & Bükkös- lucfenyves & LF $50-70 \% ;$ B $20-30 \%$ & 0 & 0 & 1 & 1 & 3 & 2 & 1 & 0 \\
\hline LF-EL & $\begin{array}{l}\text { Egyéb lomb elegyes- } \\
\text { lucfenyves }\end{array}$ & LF 50-70\%; EL 20-30\% & 0 & 0 & 1 & 1 & 3 & 2 & 1 & 0 \\
\hline LF-F & Fenyő elegyes-lucfenyves & LF $50-70 \%$; F 20-30\% & 0 & 0 & 1 & 1 & 3 & 2 & 1 & 0 \\
\hline VF & Vörös fenyves & $V F>=70 \%$ & 0 & 0 & 1 & 1 & 3 & 2 & 1 & 0 \\
\hline EGYF & Egyéb fenyves & EGYF> $=70 \%$ & 0 & 0 & 1 & 1 & 3 & 2 & 1 & 0 \\
\hline EGYF-E & Elegyes-egyéb fenyves & EGYF $50-70 \%$; EL $20-30 \%$ & 0 & 0 & 1 & 1 & 3 & 2 & 1 & 0 \\
\hline
\end{tabular}

Az Adattárban hivatalosan nyilvántartott 101 darab faállománytípus besorolását ezután fedvénybe hoztuk a NÉBIH országos erdőtérkép geo-adatbázisával. Minden egyes faállománytípust, amelyet korábban megfeleltettünk az adott pollennaptári állapotnak (országos modelltérképek) leosztályoztuk az adott hónap pollenkoncentráció értékével.

Az országos faállománytípus adatok az Adattár adatai alapján minden este frissülnek, ami a NÉBIH Erdőtérkép nyilvántartásában is folyamatosan megjelenik. Az időrendbe füzött modelltérképek egy vizuális pollennaptárt alkotnak. A pollennaptári térképek felbontása módosítható, így országos, regionális vagy helyi felbontásban is megjelenítheti a decemberjúliusi időszakban pollent kibocsátó erdőrészleteket. 


\section{EREDMÉNYEK ÉS MEGVITATÁSUK}

Az összehasonlítás során a 2017. július 6-ai erdőállapot adatokra készítettük el a faállománytípusok pollenkibocsátás szerinti besorolását. Az Adattár erdőpoligonjai, valamint azok faállománytípusai évente változnak az erdőtervezéstől függően. Mivel a változás mértéke elenyésző, ezért az állományadatokat statikusnak lehet tekinteni. A pollenkibocsátás térképfedvényei alá az erdészeti nagytájak kerültek megjelenítésre, mint a domborzati viszonyokról tájékoztató fedvény.

A fent leírt besorolás és osztályozási eljárás során a decemberi állapottól indulóan minden hónapban jellemző pollenkoncentráció alapján besorolt erdőrészletek országos eloszlásáról modelltérképeket is készítettünk, amelyek országos képet alkotnak a nyilvántartott erdők virágzásáról, közvetve azok pollenkibocsátásáról. Fontos kitérni arra, hogy a decemberben virágzó fajok közül a nyírfélék családjába (Betulaceae) tartozó éger (Alnus glutinosa) jelenléte ugyan nem túl nagy az országban, de fontosnak találtuk, hogy térkép készüljön a decemberi pollenkibocsátásról. Az égeresek közül a mézgás égerest, valamint az elegyesmézgás égeres állományokat vettük be a térképi ábrázolásba. A közönséges mogyoró (Corylus avellana) esetében a jövőben fejlesztési igény van rá, hogy az erdőrészletleíró lapok megjegyzés mezőjére futtatott lekérdezés során szintén kimutathatók legyenek azok az erdőrészletek, melyekben közönséges mogyoró található. Itt meg kell jegyezni, hogy országos szinten a cserjefajok leírása nem egyöntetü.

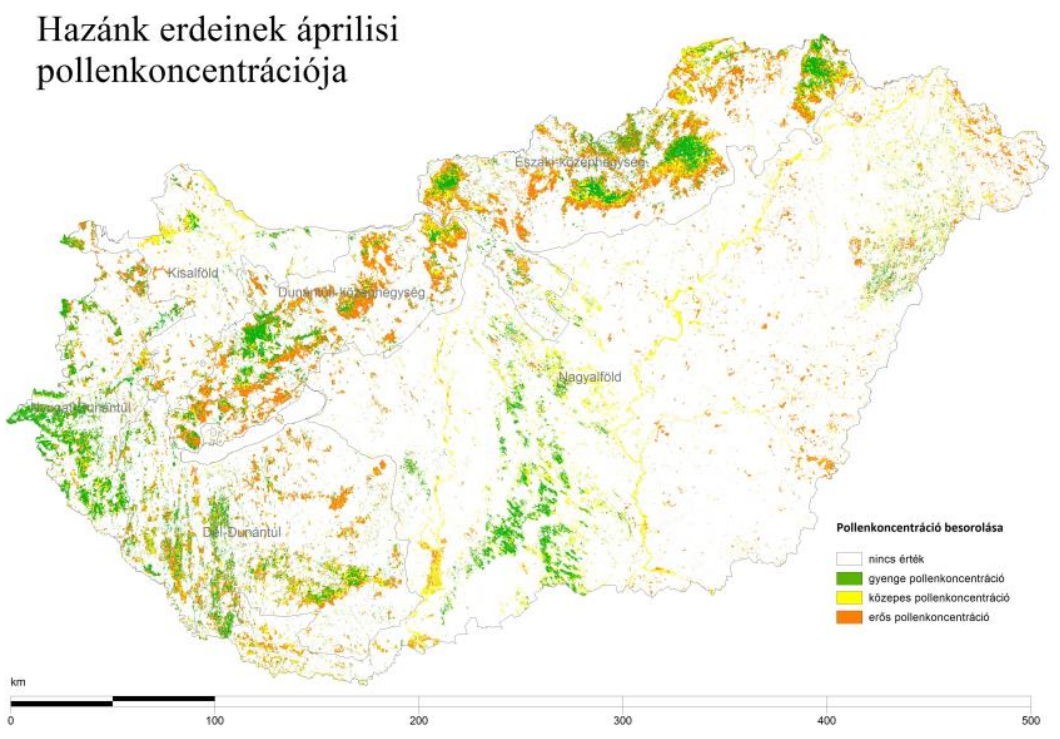

2. ábra: Áprilisi pollenkibocsátás országos eloszlása a 2015-évi ÁNTSZ pollenjelentés alapján (NÉBIH-El 2018).

Figure 2: Distribution of pollen emissions of Hungarian forests in April based on the 2015 ÁNTSZ Pollen Report (NÉBIH-EI 2018). 

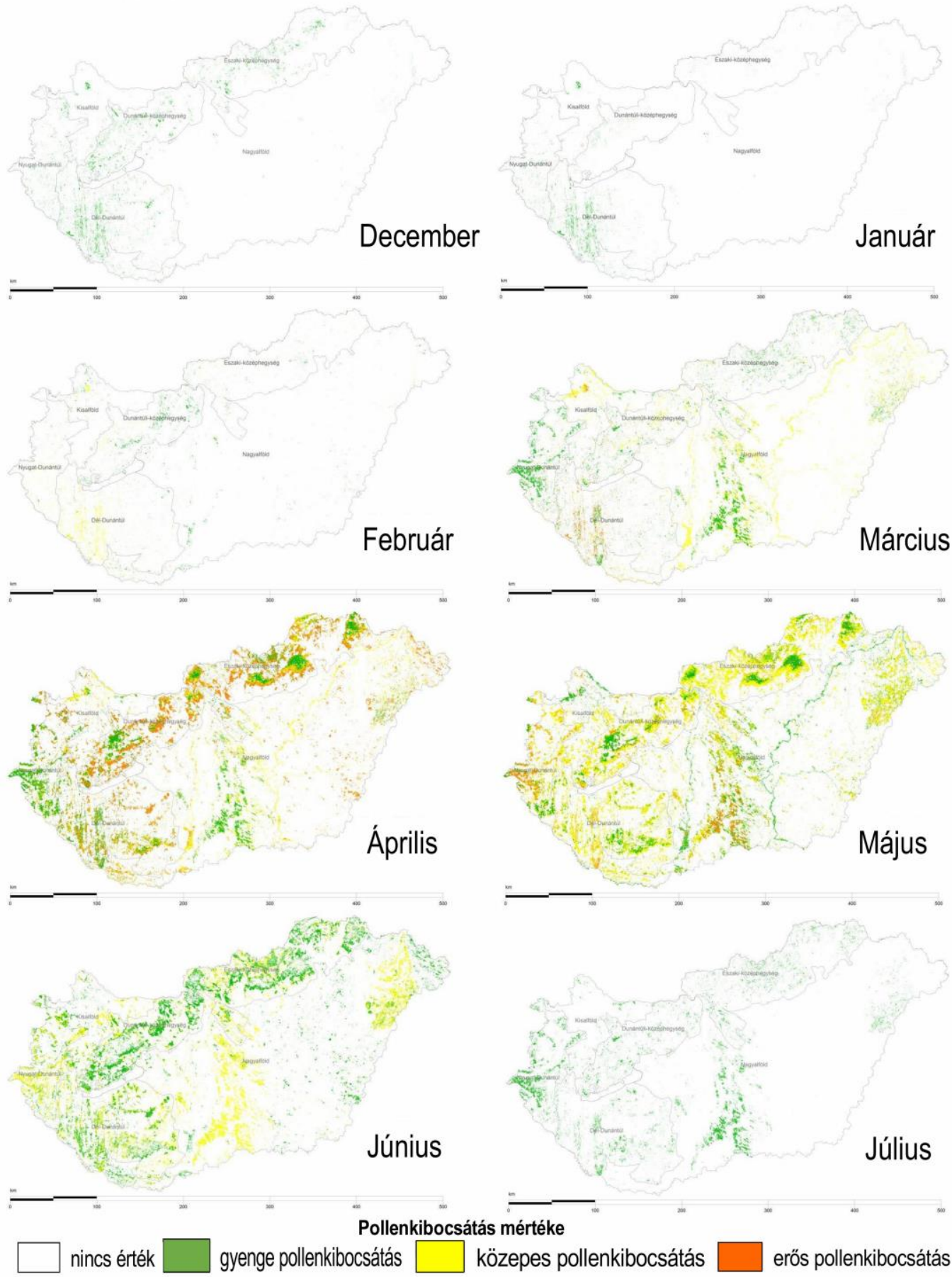

3. ábra: Pollenkibocsátás országos eloszlása a 2015-évi ÁNTSZ pollenjelentés alapján (NÉBIH-El 2018). Figure 3: Distribution of pollen emissions of Hungarian forests based on the 2015 ÁNTSZ pollen report (NÉBIH-EI 2018). 
Az Adattár állapotadatainak megfelelő kimutatások térképi fedvények formájában is elérhetők a (NÉBIH) Erdészeti Igazgatóság által müködtetett országos erdőtérképen (URL 4). Az Adattár napi frissítései révén folyamatosan frissülnek a térképi alakzatok, valamint a hozzájuk tartozó faállománytípus adatok. Kiragadva a 2015. év áprilisi pollenkoncentrációt szemléltető térképet (2. ábra) szembetűnő, hogy hazánk erdeinek virágzása áprilisban érte el a maximumát, majd fokozatosan csökken július végéig, amint azt a mellékelt ábrák is mutatják az általunk készített modell (3. ábra) szerint.

A szakirodalmi hivatkozások szerint az erdei növényfajok virágzása éves szinten igen hasonló, és az átlagosnak tekintett időjárású évek közötti ingadozás rendszerint kismértékü. Elemezve a virágzás szempontjából meghatározó 2015-évi meteorológiai paramétereket elmondható, hogy a vizsgált év éves középhőmérséklete az 1901-óta mért meteorológiai adatok alapján a harmadik legmelegebbnek bizonyult (OMSZ 2016). Az Országos Meteorológiai Szolgálat a 2014-es évben szintén igen magas éves középhömérsékleti adatot közölt, tehát a pollenjelentésben vizsgált év követte az átlagosnál melegebb trendet, és 2015-ben az éves középhőmérséklet lineáris trendjének növekedése az elmúlt harminc évhez képest $+1,54^{\circ} \mathrm{C}$-ot mutat.

3. táblázat: 2012-2015-évi pollenkoncentráció adatok összehasonlitása a NÉBIH Adattár alapján február-március hónapokban (NÉBIH 2017).

Table 3: Comparison of 2012-2015 pollen concentration data by the NÉBIH Data Inventory in

February-March (NÉBIH 2017).

\begin{tabular}{|c|c|c|c|c|c|}
\hline \multicolumn{7}{|c|}{ Pollenkoncentráció (db erdőrészlet) } \\
\hline \multirow{2}{*}{ hónapok } & évek & nincs adat & $\begin{array}{c}\text { gyenge } \\
\text { pollenkoncentráció }\end{array}$ & $\begin{array}{c}\text { közepes } \\
\text { pollenkoncentráció }\end{array}$ & $\begin{array}{c}\text { erös } \\
\text { pollenkoncentráció }\end{array}$ \\
\hline \multirow{2}{*}{ Február } & 2012 & 495821 & 22894 & - & - \\
\cline { 2 - 6 } & 2015 & 479223 & 16598 & 22894 & - \\
\hline \multirow{2}{*}{ Március } & 2012 & 285610 & 109379 & 6784 & 116942 \\
\cline { 2 - 6 } & 2015 & 349178 & 61060 & 85583 & 22894 \\
\hline
\end{tabular}

A 2015. évet megelőzően 2012-ből állnak rendelkezésre pollen adatok. Ha a 2012-évi adatokat összehasonlítjuk a 2015-évi pollenjelentéssel (3. táblázat), akkor a virágzás intenzitásában jelentős szórás figyelhető meg a kora tavaszi időszakban. Január és február hónapok szinte teljesen kiesnek a pollenkibocsátás tekintetében. A virágzó fajok esetében 2012 februárjában még nem volt jelentős a pollenkibocsátás. A februári középhömérséklet az 1981-2010 közötti átlaghoz képest $4,6{ }^{\circ} \mathrm{C}$ volt alacsonyabb, amely a késői igen fagyos időjárás következményének tekinthető 2012-ben. Ugyanakkor márciusra jellemző enyhe januárral kezdödött a 2012-es év, amely kedvezett volna a nyír és a mogyoró virágzásának, de ennek ellenére csak február végén, március elején kezdtek nyílni a korán virágzó fajok. Az átlagosnál melegebb időjárás következtében márciusban intenzívebb virágzás következett be. Márciusban az erdei fa virágzását a 30 éves (1981-2010) átlagos adatokhoz képest 
kimagasló napfénytartam is segítette. A szélirány relatív gyakoriságát tekintve a Pestszentlőrinci mérések alapján megállapítható, hogy nőtt az ÉNy-i irányú szélgyakoriság 2012-ben, feltehetően a jelentős februári hideg északi ciklonok miatt. Emellett a január bizonyult a legszelesebb hónapnak, mely a pollenszórás adatait szintén befolyásolta.

Összefoglalóan megállapítható, hogy a modelltérképekhez felhasznált pollenkibocsátási adatok a sok éves átlaghoz viszonyított fenti eltérés miatt valószínüleg jelentős hibával terheltek. Növeli a bizonytalanságot, hogy a pollen adatok jelenleg statikus elemei a modellnek, amit a rendszer fejlesztésének keretében javítani szükséges.

\section{ÖSSZEFOGLALÁS}

A modelltérképek jól szemléltetik a fafajok átlagos virágzási jellemzöit és a pollennaptári állapotnak megfelelően decembertől júliusig megmutatják az egyes hónapokban számottevő mennyiségü pollent kibocsátó erdőrészleteket. A pollentérképek használatával információkat kaphatunk az erdőterületek virágzási folyamatairól, ami alapján könnyebben becsülhető lehet az erdőállományok termőképessége. Amennyiben megoldható lesz a pollenadatok folyamatos aktualizálása, akkor a virágzási adatok alapján pontosabban becsülhető lehet az adott évi magtermés mértéke, területi eloszlása. Az állományalkotó fafajok - bükk, ill. tölgy és nyár fajok - esetében minden évben magas a szaporítóanyag felhasználás. A termés elörejelzése, ill. becslése jelenleg nagy bizonytalansággal történik, ami megnehezíti mind a természetes erdőfelújitások, mind a mesterséges erdősítések tervezését. A pollenkibocsátás modellezése az erdőállományok virágzási kapacitására ad közvetett információt, és ezen keresztül célirányosabban lehet felkészülni a termés begyüjtésére, ill. a természetes felújítások tervezésére is.

A pollenkibocsátási térképek nagy segítséget adhatnak a méhlegeltetés tervezéséhez is. A méhészek számára pollennaptári térképek kiindulási alapot biztosithatnak a gyüjtés tervezéséhez, a meteorológiai elörejelzések figyelembevételével. A térképek minden felbontásban jól mutatják az adott időszakban virágzó faállománytípusokat, ill. fafajok fellelhetőségét, és a várható időjárás függvényében a kaptárak vándoroltatása, szállitása és kihelyezése könnyebben szervezhetővé tehető.

A pollen érzékenyek számára is hasznos lehet hazánk erdeinek pollentérképe. A virágzási időszakban fontos információ, milyen területeket érdemes elkerülniük és mely területeken kisebb a pollenterhelés. A pollennaptári térképekkel elöre felkészülhetnek a lakóhelyük közelében várható, számukra érzékenységet okozó fafajok pollenkibocsátásának kezdetére, ezáltal a gyógyszeres megelőzés időben történő megkezdésére. Könnyen nyomon követhető például, hogy a tél végén, tavasz elején virágzó fajok száma, gyakorisága és pollenkibocsátása (pl. mogyoró, éger, nyír) jóval kisebb, mint a hazánk egész területén nagy tömegben előforduló tölgyféléké, amelyek szokásos virágzása április-májusra esik. 
A térképek alkalmazhatósága további vizsgálatokkal, terepi megfigyelésekkel, helyi mikroklíma adatok beépitésével, valamint pontosított, ill. aktualizált észlelési adatsorok felhasználásával tovább fejleszthető. A vegetáció müholdas megfigyelése az elmúlt időszakban egyre nagyobb hangsúlyt kap a mezőgazdasági kultúrák tanulmányozásában, véleményünk szerint az erdészeti célokra szánt megfigyelésekre is érdemes összpontosítani, hiszen a virágnyilás pontos megfigyelése nem csak a kiváló magyar méztermelés hatékonyságát képes növelni, hanem hazánk erdeinek generatív megújuló képességére is hatással van. Távlati cél egy többváltozós modell megalkotása, mely különböző idősorokat (éves, havi, dekád -megoszlásban) vetne össze a hőmérséklet és egyéb időjárási viszonyok figyelembevételével.

Eddig nem állt rendelkezésre olyan adat, amely célirányosan a hazai erdőterületek pollenkoncentrációját mutatta volna be. A modelltérképek által biztosított információk tájékoztató jellegüek, s kiemelendő, hogy a 2015-évi pollennaptári virágzási adatokra támaszkodnak, s bár a virágzás időpontja minden évben eltérő lehet a középhőmérséklet függvényében, mégis jó kiinduló alapot adhatnak a jövőbeni kutatásokhoz.

\section{KÖSZÖNETNYILVÁNÍTÁS}

Köszönjük a NÉBIH Erdészeti Igazgatóság által nyújtott technikai segítséget, valamint Wisnovszky Károlynak, hogy lehetővé tette az Országos Erdőállomány Adattár adataival való munkát. A kézirat közlését a 2017-1.3.1- VKE-2017-00022 számú, valamint a VEKOP2.1.1-15-2016-00166 sz. pályázat támogatta.

\section{IRODALOMJEGYZÉK}

Astinet H. 1989: Quo vadis Waldbaumpollenkorn? Ernstes um den Wald - einmal anders. Selbstverlag, Laudenbach, 61.

Bartha D. \& Mátyás Cs. 1995: Erdei fa- és cserjefajok előfordulása Magyarországon. Saját kiadás, Sopron, 223.

Bordács S. 1994: Virágzásbiológiai megfigyelések kocsányos tölgy (Quercus robur L.) egyedeken. Erdészeti és Faipari Tudományos Közlemények 40-41: 53-65.

Bordács S. 1997: Pedunculate oak (Quercus robur L.) seed orchard and clone tests in Hungary. In: Kim C. Steiner (ed): Diversity and Adaptation in Oak Species. Proceedings, II. Conference of IUFRO Working Party on Genetics of Quercus, State College Pennsylvania, USA 12-17 October, 209-216.

Eriksson N.E. 1978: Allergy to pollen from different deciduous trees in Sweden. An investigation with skin tests, provocation tests and the radioallergosorbent test (RAST) in springtime hay fever patients. Allergy 33(6): 299-309. DOI: 10.1111/i.1398-9995.1978.tb01555.x

Fritsch 0. 2012: Erdei méhlegelö (Kézikönyv gyakorló méhészek számára). Magánkiadás, Budapest, 430.

Lin R.Y., Clauss A.E. \& Bennett E.S. 2002: Hypersensitivity to common tree pollens in New York City patients. Allergy and Asthma Proceedings 23(4): 253-258. 
Makra L., Juhász M., Borsos E. \& Béczi R. 2004: Meteorological variables connected with airborne ragweed pollen in Southern Hungary. International Journal of Biometeorology, 49(1): 37-47. DOI: 10.1007/s00484004-0208-4

Makra L. 2008: A parlagfü Magyarországon. Természet Világa 139(11): 502.

Makra L., Matyasovszky I., Tusnády G., Wang Y. \& Csépe Z. 2016: Biogeographical estimates of allergenic pollen transport over regional scales: Common ragweed and Szeged, Hungary as a test case. Agricultural and Forest Meteorology 221: 94-110. DOI: 10.1016/i.agrformet.2016.02.006

Makra L., Matyasovszky I., Guba Z., Karatzas K. \& Anttila P. 2011: Monitoring the long-range transport effects on urban PM10 levels using 3D clusters of backward trajectories. Atmospheric Environment 45: 26302641. DOI: $10.1016 /$ j.atmosenv.2011.02.068

Pjatnickij S.S. 1954. Selection of oaks. Goslesbumisdat, Moscow - Leningrad.

Wang X.Y., Tian Z.M., Ning H.Y. \& Wang X.Y. 2017: The ambient pollen distribution in Beijing urban area and its relationship with consumption of outpatient anti-allergic prescriptions. European Review for Medical and Pharmacological Sciences 21 (3 Suppl): 108-115.

\section{ONLINE FORRÁSOK}

URL 1: Országos Magyar Méhészeti Egyesület honlapja http://mehlegelo.omme.hu Letöltés ideje: 2018.10.01.

URL 2: Országos Meteorológiai Szolgálat, Elmúlt évek időjárása 2015. https://www.met.hu/eghajlat/magyarorszag_eghajlata/eghajlati_visszatekinto/elmult_evek_idojarasa/ Letöltés ideje: 2018.05.01.

URL 3: Udvardy O.; Mányoki G.; Magyar D. 2016: ÁNTSZ Aerobiológiai Hálózatának tájékoztatója OKK-OKI 6.old. http://oki.antsz.hu/files/dokumentumtar/Éves\%20jelentés\%202015.pdf Letöltés ideje: 2018.05.01.

URL 4: Nemzeti Élelmiszerlánc-biztonsági Hivatal honlapja, erdőtérkép: https://erdoterkep.nebih.gov.hu Letöltés ideje: 2018.05.01.

Érkezett: 2019. február 1.

Közlésre elfogadva: 2019. június 25. 